\title{
PEMBAHARUAN HUKUM TATA NEgARA INDONESIA DALAM RANGKA MEWUJUDKAN CITA NEGARA HUKUM NASIONAL
}

\author{
Titik Triwulan Tutik \\ UIN Sunan Ampel Surabaya| JI. A. Yani I 17 Surabaya \\ tt_titik@yahoo.com
}

\begin{abstract}
Legal products or legislation as objects of Constitutional Law contain elements of dynamics that are closely related to the movements and needs of individuals in society and the growth of state organizations. Considering the interrelation between Constitutional Law and social changes, it is obvious that what is important in Constitutional Law is not just studying the Constitution and legislation, but more pressure should be given to the process of the Act. In this context, awareness and renewal of ways of thinking in the field of Constitutional Law are needed so that the legal narrowness caused by the lack of extensive legal treasury no longer appears in the form of legal thinking or mere juridisch denken, which results in a narrow mindset in the form of imitating the rules. rules only. Constitutional law not only pays attention to a formal perspective, but also a functional angle, so that it will always be dynamic. Keywords: legal reform, the ideals of the rule of law
\end{abstract}

Abstrak: Produk-produk hukum atau perundang-undangan sebagai obyek Hukum Tata Negara mengandung unsur dinamika yang erat hubungannya dengan gerak dan kebutuhan-kebutuhan individu dalam masyarakat dan pertumbuhan organisasi negara. Mengingat adanya interrelasi antara Hukum Tata Negara dan perubahan-perubahan sosial, maka nyatalah bahwa yang penting dalam Hukum Tata Negara bukanlah sekedar mempelajari UUD dan peraturan perundangan saja, tapi tekanan hendaklah lebih diberikan kepada proses terjadinya UU. Dalam konteks ini diperlukan kesadaran dan pembaharuan cara berpikir di bidang Hukum Tata Negara, sehingga legal narrowness yang disebabkan kurang luasnya perbendaharaan hukum tidak lagi muncul dalam bentuk legal thinking atau juridisch denken semata-mata, yang mengakibatkan cara berpikir yang picik dalam bentuk menirukan bunyi peraturanperaturan saja. Hukum Tata Negara tidak saja memperhatikan sudut pandang formal, tapi juga sudut fungsional, sehingga akan selalu bersifat

AL-DAULAH: JURNAL HUKUM DAN PERUNDANGAN ISLAM

VOLUME 8, NOMOR 2, OKTOBER 2018

p-ISSN 2089-0109; e-ISSN 2503-0922

Homepage: http://jurnalfsh.uinsby.ac.id/index.php/aldaulah

Email: judulsj@gmail.com 
dinamis.

Kata Kunci: pembaharuan hukum, cita negara hukum

\section{Pendahuluan}

Pemikiran negara hukum dimulai sejak Plato dengan konsepnya "bahwa penyelenggaraan negara yang baik ialah yang didasarkan pada pengaturan (hukum) yang baik yang disebutnya dengan istilah nomoi". ${ }^{1}$ Kemudian ide tentang negara hukum populer pada abad ke-17 sebagai akibat dari situasi politik di Eropa yang didominasi oleh absolutisme. ${ }^{2}$

Konsep negara hukum selanjutnya berkembang dalam dua sistem hukum yaitu sistem Eropa Kontinental seperti Perancis, Belanda, dan negara-negara bekas jajahan keduanya dengan istilah Rechtsstaat dan sistem Anglo-Saxon dengan istilah Rule of Law. Rule of Law berkembang di negara-negara Anglo-Saxon, seperti Inggris, Amerika Serikat, dan Australia.

Konsep negara hukum Eropa Kontinental Rechtsstaat dipelopori oleh Immanuel Kant dan Frederich Julius Stahl. Menurut Stahl konsep ini ditandai oleh empat unsur pokok: 1) pengakuan dan perlindungan terhadap hak-hak asasi manusia; 2) negara didasarkan pada teori trias politica; 3) pemerintahan diselenggarakan berdasarkan undang-undang (wetmatig bertuur); dan 4) ada peradilan administrasi negara yang bertugas menangani kasus perbuatan melanggar hukum oleh penerintah (onrechtmatige overheidsdaad). ${ }^{3}$ Sedangkan Konsep negara hukum Anglo-Saxon Rule of Law dipelopori oleh A.V Dicey (Inggris). Menurut A.V Dicey,

\footnotetext{
I Pemikiran tentang Negara hukum ini muncul, karena pada awalnya konsep suatu negara dalam pandangan masyarakat sangat sederhana, di mana tugas dan fungsi negara hanya sebagai "penjaga malam (nachtwachtes staat)" saja. Konsep negara sebagai penjaga malam ini, artinya pemerintah (negara) hanya menjadi pelaksana segala keinginan rakyat.

2 Muhammad Tahir Azhary, Negara Hukum: Suatu Studi tentang Prinsip-prinsipnya Dilihat dari Segi Hukum Islam, Implementasinya pada Periode Negara Madinah dan Masa Kini, (Jakarta: Bulan Binting, 1992), 66.

3 Selanjutnya konsep Stahl ini dinamakan negara hukum formil, karena lebih menekankan pada suatu pemerintahan yang berdasarkan undang-undang. Ibid., 66-67. Bandingkan dengan pendapat Hans Kelsen dalam Denny Indrayana, "Negara Hukum Pasca Soeharto: Transisi Menuju Demokrasi vs Korupsi", Jurnal Konstitusi, Mahkamah Konstitusi RI Vol. I No. I, Juli 2004, 106.
} 
konsep rule of law ini menekankan pada tiga tolok ukur: 1) supremasi hukum (supremacy of law); 2) persamaan dihadapan hukum (equality before the law); 3) konstitusi yang didasarkan atas hak-hak perorangan (the constitution based on individual rights). ${ }^{4}$

Berdasarkan pertimbangan para pakar tersebut, maka Negara hukum hakekatnya adalah negara yang menolak melepaskan kekuasaan tanpa kendali, yaitu bahwa negara mempolakan kehidupanya berdasarkan hukum yang adil dan demokratis. Kekuasaan negara di dalamnya, harus tunduk pada "aturan main". ${ }^{5}$

Prinsip negara hukum ini dibangun atas 4 (empat) syarat, yaitu: Pertama, negara dibangun berdasarkan atas konstitusi. Kedua, tranparansi dan akuntabilitas publik atas setiap kebijakan negara. Ketiga, jaminan kekuasaan kehakiman yang bebas dan independen. Keempat, perlindungan atas hak asasi manusia.

Bagaimana dengan konsep Negara hukum di Indonesia? Mengikuti pendapat Garry F. Bell dalam bukunya The New Indonesion Laws Relating to Regional Autonomy Good Intentions, Confusing Laws seperti dikutip Denny Indrayana, sebagai terminologi negara hukum (a nation of law) dalam kontek hukum Indonesia lebih mendekati konsep hukum kontinental (rechsstaat) dibandingkan konsep rule of law di negara-negara Anglo-Saxon. ${ }^{6}$ Berbeda dengan Bell, R.M. Ananda B. Kusuma, melihat bahwa Republik Indonesia menganut asas Rechtsstaat Kontinental dan asas Rule of law. ${ }^{7}$

Menyikapi berbagai pendapat tersebut, Penulis tidak bertujuan mencari perbedaan pandangan di antaranya, karena secara prinsipil

\footnotetext{
${ }^{4}$ Muhammad Tahir Azhary, Negara Hukum: Suatu Studi tentang Prinsip-prinsipnya..., 67.

${ }^{5}$ Titik Triwulan Tutik, Konstruksi Hukum Tata Negara Indonesia Pasca Amandemen UUD 1945, (Jakarta: Kencana Prenada Media Group, 201 I), 62.

${ }^{6}$ Denny Indrayana,"Negara Hukum Pasca Soeharto: Transisi Menuju Demokrasi vs Korupsi", Jurnal Konstitusi, Mahkamah Konstitusi RI Vol. I No. I, Juli 2004, 106.

7 Pandangan ini dipertegas umpamanya, supremacy of law sebagaimana termaktub pada kunci pokok (I): I) equality before the law, tercermin di UUD 1945 Pasal 27 ayat (I); dan 2) Constitution Based on Human Rights tercermin pada Sistem Konstitusional yang memuat HAM (Pasal 27 ayat (2); Bab XA, Pasal 30, Pasal 3 I dan Pasal 34). R.M. Ananda B. Kusuma,"Sistem Pemerintahan Indonesia". Jurnal Konstitusi, Mahkamah Konstitusi RI Vol. I No. I, Juli 2004, I 46.
} 
keduanya ada persamaan, sebagaimana dikatakan N.W Barber posisi untuk tidak terlalu membedakan konsep rechtsstaat dan konsep rule of law, antara lain karena persamaan mendasar di antara keduannya. ${ }^{8}$

Indonesia secara formil sudah sejak tahun 1945 (UUD 1945 sebelum perubahan) mendeklarasikan diri sebagai negara hukum seperti dalam Penjelasan UUD 1945 dinyatakan, "Indonesia adalah negara yang berdasarkan hukum dan bukan negara yang berdasarkan kekuasaan belaka". Konsep negara hukum Indonesia dipertegas UUD 1945 hasil perubahan dalam Pasal 1 ayat 3 yang menetapkan: "Negara Indonesia adalah Negara Hukum".

Apabila meneliti UUD 1945 secara seksama, maka ditemukan unsur-unsur negara hukum tersebut di dalamnya, yaitu sebagai berikut; pertama, prinsip kedaulatan rakyat (Pasal 1 ayat 2), kedua, pemerintahan berdasarkan konstitusi (penjelasan UUD 1945), ketiga, jaminan terhadap hak-hak asasi manusia (Pasal 27, 28, 28A s.d 28I, 29, 31), keempat, pembagian kekuasaan (Pasal 2, 4, 16, 19), kelima, pengawasan peradilan (pasal 24), keenam, partisipasi warga negara (pasal 28), ketujuh, sistem perekonomian (Pasal 33).

\section{Esensi Negara Hukum}

Esensi dari negara hukum yang berkonstitusi adalah perlindungan terhadap hak asasi manusia. Oleh karena itu, isi dari setiap konstitusi tersebut dapat dijelaskan sebagai berikut, negara merupakan organisasi kekuasaan berdasarkan kedaulatan rakyat, agar kekuasaan ini tidak liar maka perlu dikendalikan dengan cara disusun, dibagi dan dibatasi, serta diawasi baik oleh lembaga pengawasan yang mandiri dan merdeka maupun oleh warga masyarakat, sehingga tidak terjadi pelanggaran terhadap hak-hak asasi manusia. Seandainya unsur jaminan terhadap hak-hak asasi manusia ini ditiadakan dari konstitusi, maka penyususnan, pembagian, pembatasan, dan pengawasan kekuasaan negara tidak diperlukan karena tidak ada lagi yang perlu dijamin dan dilindungi.

8 Ibid., 102. 
Karena esensi dari setiap konstitusi adalah perlindungan terhadap hak-hak asasi manusia, maka menuntut adanya kesamaan setiap manusia di depan hukum. Tiadanya kesamaan akan menyebabkan satu pihak merasa lebih tinggi dari pihak lainnya, sehingga akan mengarah pada terjadinya penguasaan pihak yang lebih tinggi kepada yang rendah. Situasi demikian merupakan bentuk awal dari anarki yang menyebabkan terlanggarnya hak-hak manusia, dan ini berarti redaksi perlindungan terhadap hak-hak asasi manusia yang terdapat dalam setiap konstitusi menjadi tidak berarti atau kehilangan makna.

Adanya kesamaan antar manusia dalam suatu negara akan memungkinkan lahirnya partisipasi aktif dari setiap orang. Partisipasi ini penting dalam suatu negara yang memiliki konstitusi, agar isi dari konstitusi sebagai hukum dasar ini merupakan kristalisasi dari keinginan-keinginan dan kehendak dari sebagian besar masyarakat, kalau tidak dapat dikatakan semua masyarakat. Partisipasi masyarakat dalam suatu negara ini merupakan esensi dari demokrasi.

\section{Eksistensi Negara Hukum Indonesia}

Eksistensi Indonesia sebagai negara hukum telah secara tegas disebutkan dalam Pasal 1 ayat (3) UUD 1945; "Indonesia ialah negara yang berdasar atas hukum (rechtsstaat)". Indikasi bahwa Indonesia menganut konsepsi welfare state terdapat pada kewajiban pemerintah untuk mewujudkan tujuan-tujuan negara, sebagaimana yang termuat dalam alinea keempat Pembukaan UUD 1945, yaitu; "Melindungi segenap bangsa Indonesia dan seluruh tumpah darah Indonesia, memajukan kesejahteraan umum, mencerdaskan kehidupan bangsa, dan melaksanakan ketertiban dunia". Tujuan-tujuan ini diupayakan perwujudannya melalui pembangunan yang dilakukan secara bertahap dan berkesinambungan dalam program jangka pendek, menengah, dan panjang. 
Menurut Philipus M. Hadjon, karakteristik negara hukum Pancasila tampak pada unsur-unsur yang ada dalam negara Indonesia, yaitu sebagai berikut:

1) Keserasian hubungan antara pemerintah dan rakyat berdasarkan asas kerukunan;

2) Hubungan fungsional yang proporsional antara kekuasaankekuasaan negara;

3) Prinsip penyelesaian sengketa secara musyawarah dan peradilan merupakan sarana terakhir;

4) Keseimbangan antara hak dan kewajiban. ${ }^{9}$

Berdasarkan penelitian M. Tahir Azhary, negara hukum Indonesia memiliki ciri-ciri sebagai berkut :

a) Ada hubungan yang erat antara agama dan negara;

b) Bertumpu pada Ketuhanan Yang Maha Esa;

c) Kebebasan beragama dalam arti positip;

d) Ateisme tidak dibenarkan dan komunisme dilarang;

e) Asas kekeluargaan dan kerukunan. ${ }^{10}$

Meskipun antara hasil penelitian Philipus M. Hadjon dan M. Tahir Azhary terdapat perbedaan, karena terdapat titik pandang yang berbeda. M. Tahir Azhary melihatnya dari titik pandang hubungan antara agama dengan negara, sedangkan Philipus M. Hadjon memandangnya dari aspek perlindungan hukum bagi rakyat. Namun sesungguhnya unsur-unsur yang dikemukakan oleh kedua pakar hukum ini terdapat dalam negara hukum Indonesia. Artinya unsur-unsur yang dikemukakan ini saling melengkapi.

Berdasarkan paparan di atas, ada perbedaan mendasar antara konsep bangunan negara hukum lain dengan negara hukum Indonesia. Bangunan negara hukum Indonesia berpijak pada landasan dasar falsafah negara yaitu Pancasila. Artinya bahwa cita-

9 Philipus M. Hadjon, Perlindungan Hukum bagi Rakyat di Indonesia (Surabaya: Bina IImu, 1987), 90.

10 M. Tahir Azhary, Negara Hukum: Suatu Study tentang Prinsip-Prinsipnya Dilihat dari Segi Hukum Islam, (Jakarta: Bulan Bintang, 1992), 70. 
cita hukum (Rechtsidee) yang dibangun dalam berbangsa dan bernegara di Indonesia pada hakekatnya adalah bersumber pada nilai-nilai luhur Pancasila.

\section{Cita Negara Hukum Indonesia}

Puncak dari negara hukum adalah cita atau cita-cita negara hukum itu sendiri. Menurut Padmo Wahjono, bahwa cita-cita negara hukum Indonesia termaktub dalam pokok-pokok pikiran yang terkandung dalam Pembukaan UUD 1945, yaitu

1. Negara melindungi segenap bangsa Indonesia dan seluruh tumpah darah Indonesia dengan berdasar atas persatuan dengan mewujudkan keadilan sosial bagi seluruh rakyat Indonesia;

2. Negara hendak mewujudkan keadilan sosial bagi seluruh rakyat Indonesia;

3. Negara berkedaulatan rakyat, berdasarkan atas kerakyatan dan permusyawaratan perwakilan;

4. Negara berdasar atas Ketuhanan Yang Maha Esa menurut dasar kemanusiaan yang adil dan beradab. ${ }^{11}$

Pokok pikiran tersebut mewujudkan cita-cita hukum (rechtsidee) yang menguasai hukum dasar negara, baik hukum yang tertulis (UUD) maupun hukum yang tidak tertulis (konvensi ketatanegaraan).

Cita-cita Negara hukum ini pada hakekatnya adalah Pancasila, falsafah dasar Negara yang pokok-pokok rumusan tujuannya dalam bernegara adalah:

1. Memajukkan kesejahteraan umum;

2. Mencerdaskan kehidupan bangsa;

3. Ikut melaksanakan ketertiban dunia yang berdasarkan kemerdekaan, perdamaian abadi, dan keadilan sosial.

Penciptaan lebih lanjut cita-cita Negara hukum ini dalam pasal-pasal UUD 1945 ialah:

I Padmo Wahjono, Sistem Hukum Nasional dalam Negara Hukum Pancasila, (Jakarta: Rajawali, 1983), 4-5. 
1. Bab XA tentang Hak Asasai Manusuia Pasal 28A sampai dengan 28J,;

2. Pasal 29 ayat (2) tentang kemerdekaan penduduk untuk memeluk agama dan beribadat;

3. Pasal 27 ayat (2) tentang hak warga Negara atas pekerjaan dan penghidupan;

4. Pasal 28 tentang kemerdekaan berserikat, berkumpul dan berpendapat;

5. Pasal 30 tentang hak dan kewajiban warga Negara dalam bela Negara;

6. Pasal 31 tentang hak warga Negara memperoleh pendidikan;

7. Pasal 33 tentang perekonomian nasional;

8. Pasal 34 tentang kesejahteraan rakyat.

Kesemua pasal-pasal tersebut mencerminkan kepentingan perorangan maupun warga Negara secara kolektif di dalam bidang bermasyarakat dan bernegara yang didasarkan pada asas bahwa setiap orang selaku perorangan maupun warganegara adalah sama kedudukannya berdasarkan hukum dan pemerintahan dan wajib menjunjung tinggi hukum dan pemerintahan tanpa kecuali.

Kerangka Dasar Hukum Tata Negara dan Uapaya Memperbaiki Sistim Hukum di Indonesia

Philipus M. Hadjon, dalam satu tulisannya, dengan mengutip tulisan D. H. Meuwissen mengatakan, bahwa hukum tata negara (klasik) lazimnya mengenai dua pilar hukum tata negara, yaitu organisasi negara dan warga negara. Dalam organisasi negara diatur bentuk negara dan sistem pemerintahan termasuk pembagian kekuasaan negara atau alat perlengkapan negara. ${ }^{12}$ Sementara Jimly Asshiddiqie dalam bukunya "Pokok-Pokok Hukum Tata Negara Indonesia Pasca Reformasi" menyebutkan materi dasar dari Hukum Tata Negara (positif) meliputi materi

12 Philipus M. Hadjon, "Pembagian Kewenangan Pusat dan Daerah", Makalah. Disampaikan pada Semiloka Rekonstruksi Politik Hukum Otonomi Daerah Yang Berbasis pada Kemandirian dan Demokratisasi di Daerah (Strategi Revisi UU No. 22 dan 25 tahun 1999), Malang, I 8-20 Pebruari 200I, 2. 
wajib dan materi pilihan. Materi wajib terdiri dari UUD 1945, organisasi dan struktur ketatanegaraan, warga Negara dan HAM, teori dan praktik peradilan tata Negara, dan teori dan praktik peradilan tata usaha Negara. ${ }^{13}$ Sedangkan materi pilihan terdiri dari; (1) lembaga perwakilan rakyar, partai politik, dan pemilu, (2) pemerintahan Negara, birokrasi, dan tata pemerintahan yang baik (good governance), (3) penegakkan hukum dan lembaga peradilan, (4) sistem hukum dan perundang-undangan, (5) pemerintahan daerah, (6) hak asasi manusia dan masalah kewarganegaraan, (7) hukum keimigrasian, (8) hukum perpajakan, anggaran, dan keuangan Negara, (9) hukum administrasi kepegawaian, (10) hukum administrasi lingkungan, (11) hukum pertanahan, (12) hukum kehutanan, dan perkebunan, dan (13) hukum bangunan. ${ }^{14}$

Era reformasi memberikan harapan besar bagi terjadinya perubahan ketatanegaraan di Indonesia, khusunya dalam rangka menuju penyelenggaraan negara yang lebih demokratis, transparan, dan memiliki akuntabilitas tinggi serta terwujudnya good governance dan adanya kebebasan berpendapat. Semuanya itu diharapkan makin mendekatkan bangsa pada pencapaian tujuan nasional sebagaimana terdapat dalam Pembukaan Undang-Undang Dasar Negara Republik Indonesia Tahun 1945. Untuk itu gerakan reformasi diharapkan mampu mendorong perubahan mental bangsa Indonesia, baik pemimpin maupun rakyat sehingga mampu menjadi bangsa yang menganut dan menjunjung tinggi nilai-nilai kebenaran, keadilan, kejujuran, tanggung jawab, persamaan, serta persaudaraan.

Pada awal era reformasi, berkembang dan populer di masyarakat banyaknya tuntutan reformasi yang didesakkan oleh berbagai komponen bangsa, termasuk mahasiswa dan pemuda. Tuntutan, itu antara lain, sebagai berikut.

${ }_{13}^{3}$ Jimly Asshiddiqie, Pokok-Pokok Hukum Tata Negara Indonesia Pasca Reformasi, (Jakarta: Buana IImu Populer, 2008), 4.

$14 \mathrm{lbid}$. 
1. Amandemen Undang-Undang Dasar Negara Republik Indonesia Tahun 1945.

2. Penghapusan doktrin dwifungsi Angkatan Bersenjata Republik Indonesia (ABRI).

3. Penegakan supremasi hukum, penghormatan hak asasi manusia (HAM), serta pemberantasan korupsi, kolusi, dan nepotisme (KKN).

4. Desentralisasi dan hubungan yang adil antara pusat dan daerah (otonomi daerah).

5. Mewujudkan kebebasan pers.

6. Mewujudkan kehidupan demokrasi. ${ }^{15}$

Tuntutan perubahan Undang-Undang Dasar Negara Republik Indonesia Tahun 1945 yang digulirkan oleh berbagai kalangan masyarakat dan kekuatan sosial politik didasarkan pada pandangan, bahwa Undang-Undang Dasar Negara Republik Indonesia Tahun 1945 belum cukup memuat landasan bagi kehidupan yang demokratis, pemberdayaan rakyat, dan penghormatan HAM. Selain itu di dalamnya terdapat pasal-pasal yang menimbulkan multi tafsir dan membuka peluang bagi penyelenggaraan negara yang otoriter, sentralistik, tertutup, dan KKN yang menimbulkan kemerosotan kehidupan nasional di berbagai bidang kehidupan.

Tuntutan perubahan Undang-Undang Dasar Negara Republik Indonesia Tahun 1945 pada era reformasi tersebut merupakan suatu langkah terobosan yang mendasar karena pada era sebelumnya tidak dikehendaki adanya perubahan Undang-Undang Dasar Negara Republik Indonesia Tahun 1945. Sikap politik pemerintah pada waktu itu kemudian diperkukuh dengan dasar hukum Ketetapan MPR Nomor IV/MPR/1983 tentang Referendum, yang berisi kehendak untuk tidak melakukan perubahan Undang-Undang Dasar Negara Republik Indonesia Tahun 1945. Apabila muncul juga kehendak mengubah Undang-Undang Dasar

15 Titik Triwulan Tutik, Restorasi Hukum Tata Negara Indonesia Berdasarkan Undang-Undang Dasar Republik Indonesia Tahun 1945, (Jakarta: Prenada Media Group, 20 I7), I. 
Negara Republik Indonesia Tahun 1945, terlebih dahulu harus dilakukan referendum dengan persyaratan yang sangat ketat sehingga kecil kemungkinannya untuk berhasil sebelum usul perubahan Undang-Undang Dasar Negara Republik Indonesia Tahun 1945 diajukan ke sidang MPR untuk dibahas dan diputus.

Dasar pemikiran yang melatarbelakangi dilakukannya perubahan Undang-Undang Dasar Negara Republik Indonesia Tahun 1945, antara lain, sebagai berikut: Pertama, Undang-Undang Dasar Negara Republik Indonesia Tahun 1945 membentuk struktur ketatanegaraan yang bertumpu pada kekuasaan tertinggi di tangan MPR yang sepenuhnya melaksanakan kedaulatan rakyat. Hal itu berakibat pada tidak terjadinya saling mengawasi dan saling mengimbangi (checks and balances) pada institusi-institusi ketatanegaraan. Penyerahan kekuasaan tertinggi kepada MPR merupakan kunci yang menyebabkan kekuasaan pemerintahan negara seakan-akan tidak memiliki hubungan dengan rakyat.

Kedua, Undang-Undang Dasar Negara Republik Indonesia Tahun 1945 memberikan kekuasaan yang sangat besar kepada pemegang kekuasaan eksekutif (presiden). Sistem yang dianut oleh Undang-Undang Dasar Negara Republik Indonesia Tahun 1945 adalah dominan eksekutif (executive heavy), yakni kekuasaan dominan berada di tangan presiden. Pada diri presiden terpusat kekuasaan menjalankan pemerintahan (chief executive) yang dilengkapi dengan berbagai hak konstitusional yang lazim disebut hak prerogatif (antara lain memberi grasi, amnesti, abolisi, dan rehabilitasi) dan kekuasaan legislatif karena memiliki kekuasaan membentuk undang-undang.

Ketiga, Undang-Undang Dasar Negara Republik Indonesia Tahun 1945 mengandung pasal-pasal yang terlalu "luwes" sehingga dapat menimbulkan lebih dari satu tafsiran (multitafsir), misalnya Pasal 7 Undang-Undang Dasar Negara Republik Indonesia Tahun 1945 (sebelum diubah) yang berbunyi "Presiden dan Wakil Presiden memegang jabatannya selama masa lima tahun dan sesudahnya dapat dipilih kembali". Rumusan pasal itu dapat ditafsirkan lebih dari satu, 
yakni tafsir pertama bahwa presiden dan wakil presiden dapat dipilih berkali-kali dan tafsir kedua adalah bahwa presiden dan wakil presiden hanya boleh memangku jabatan maksimal dua kali dan sesudah itu tidak boleh dipilih kembali. Contoh lain adalah Pasal 6 ayat (1) Undang-Undang Dasar Negara Republik Indonesia Tahun 1945 (sebelum diubah) yang berbunyi "Presiden ialah orang Indonesia asli". Undang-Undang Dasar Negara Republik Indonesia Tahun 1945 tidak memberikan penjelasan dan memberikan arti apakah yang dimaksud dengan orang Indonesia asli. Akibatnya rumusan itu membuka tafsiran beragam, antara lain, orang Indonesia asli adalah warga negara Indonesia yang lahir di Indonesia atau warga negara Indonesia yang orang tuanya adalah orang Indonesia.

Keempat, Undang-Undang Dasar Negara Republik Indonesia Tahun 1945 terlalu banyak memberikan kewenangan kepada kekuasaan Presiden untuk mengatur hal-hal penting dengan undang-undang. Undang-Undang Dasar Negara Republik Indonesia Tahun 1945 menetapkan bahwa Presiden juga memegang kekuasaan legislatif sehingga Presiden dapat merumuskan hal-hal penting sesuai dengan kehendaknya dalam undang-undang. Hal itu menyebabkan pengaturan mengenai MPR, Dewan Perwakilan Rakyat (DPR), Badan Pemeriksa Keuangan (BPK), Mahkamah Agung (MA), HAM, dan pemerintah daerah disusun oleh kekuasaan Presiden dalam bentuk pengajuan rancangan undang-undang ke DPR.

Kelima, rumusan Undang-Undang Dasar Negara Republik Indonesia Tahun 1945 tentang semangat penyelenggara negara belum cukup didukung ketentuan konstitusi yang memuat aturan dasar tentang kehidupan yang demokratis, supremasi hukum, pemberdayaan rakyat, penghormatan hak asasi manusia (HAM), dan otonomi daerah. Hal itu membuka peluang bagi berkembangnya praktik penyelenggaraan negara yang tidak sesuai dengan Pembukaan Undang-Undang Dasar Negara Republik Indonesia Tahun 1945, antara lain, sebagai berikut: 
a. Tidak adanya saling mengawasi dan saling mengimbangi (checks and balances) antarlembaga negara dan kekuasaan terpusat pada Presden.

b. Infrastruktur politik yang dibentuk, antara lain partai politik dan organisasi masyarakat, kurang mempunyai kebebasan berekspresi sehingga tidak dapat berfungsi sebagaimana mestinya.

c. Pemilihan umum (pemilu) diselenggarakan untuk memenuhi persyaratan demokrasi formal karena seluruh proses dan tahapan pelaksanaannya dikuasai oleh pemerintah.

d. Kesejahteraan sosial berdasarkan Pasal 33 Undang-Undang Dasar Negara Republik Indonesia Tahun 1945 tidak tercapai, justru yang berkembang adalah sistem monopoli, oligopoli, dan monopsoni. ${ }^{16}$

Kenyataan demikian mendorong semangat perubahan UUD 1945 dalam rangka terbangunnya struktur ketatanegaraan yang lebih demokratis. Perubahan UUD 1945 sejak reformasi telah dilakukan sebanyak empat kali, yaitu:

1. Perubahan pertama disyahkan pada tanggal 19 Oktober 1999;

2. Perubahan kedua disyahkan pada tanggal 18 Agustus 2000;

3. Perubahan ketiga disyahkan pada tanggal 10 November 2001; dan

4. Perubahan keempat disyahkan pada tanggal 10 Agustus 2002.

a. Perubahan Pertama UUD 1945

Perubahan terhadap UUD 1945 terjadi setelah berkumandangnya tuntutan reformasi, yang di antaranya berkenaan dengan reformasi konstutisi (constitusional reform). Perubahan pertama terhadap UUD 1945 dilakukan upaya: Pertama, mengurangi/mengendalikan kekuasaan Presiden; Kedua, hak

16 Majelis Permusyawaratan Rakyat RI, Panduan Pemasyarakatan Undang-Undang Dasar Negara republik Indonesia Tahun 1945 dan Ketetapan Majelis Permusyawaratan Rakyat Republik Indonesia, (Jakarta: Sekretariat Jenderal MPR RI, 20 I 2), I I - 2. 
legislasi dikembalikan ke DPR, sedangkan presiden berhak mengajukan RUU kepada DPR.

b. Perubahan Kedua UUD 1945

Perubahan ke dua terhadap UUD 1945 dilakukan pada subtansi yang meliputi: (1) pemerintahan daerah; (2) wilayah Negara; (3) warganegara dan penduduk; (4) hak asasi manusia; (5) pertahanan dan keamanan Negara; (6) bendera, bahasa, lambang negara dan lagu kebangsaan; dan (7) lembaga DPR, khususnya tentang keanggotaan, fungsi, hak, maupun tentang cara pengisiannya.

\section{c. Perubahan Ketiga UUD 1945}

Perubahan subtansi amandemen ke tiga meliputi antara lain: (1) kedudukan dan kekuasaan MPR; (2) eksistensi Negara hukum Indonesia; (3) jabatan Presiden dan wakil Presiden termasuk mekanisme pemilihan; (4) pembentukan lembaga baru dalam sistem ketatanegaraan RI; (5) pengatura tambahan bagi lembaga DPK; dan (6) Pemilu.

\section{d. Perubahan Keempat UUD 1945}

Perubahan keempat terhadap UUD 1945 ini merupakan perubahan terakhir yang menggunakan Pasal 37 UUD 1945 praamandemen yang dilakukan oleh MPR. Ada sembilan item pasal subtansial pada perubahan keempat UUD 1945, antara lain: (1) keanggotaan MPR, (2) pemilihan Presiden dan wakil Presiden tahap kedua, (3) kemungkinan presiden dan wakil presiden berhalangan tetap, (4) tentang kewenangan presiden, (5) hal keuangan negara dan bank sentral, (6) pendidikan dan kebudayaan, (7) perekonomian nasional dan kesejahteraan sosial, (8) aturan tambahan dan aturan peralihan, dan (9) kedudukan penjelasan UUD 1945.

Mengomentari terhadap pembaharuan hukum tata Negara Indonesia melalui perubahan UUD 1945, Tim Lindsey mengatakan: 
Di luar semua kesulitan itu, kemajuan sedang berjalan (dalam hukum tata Negara Indonesia): UUD 1945 setelah Perubahan Keempat masih memiliki banyak kekurangan, tetapi UUD 1945 sekarang adalah sebuah dokumen yang lebih baik, tiada bandingannya. Secara historis, hanya sedikit Negara yang berhasil mengadopsi reformasi-reformasi konstitusi seefektif Indonesia, murni melalui perdebatan-perdebatan di parlemen. ${ }^{17}$

Berdasarkan kenyataan demikian memberikan sinyalemen perlunya dilakukan pembaharuan hukum tata Negara Indonesia lagi yang lebih komprehensip, menyeluruh dan sistemik, sehingga permasalahan-permasalahan fundamental tersebut dapat terselesaikan.

\section{Pembaharuan Hukum Tata Negara Indonesia}

Istilah "Pembaharuan" dapat diartikan sebagai sebuah proses memperbarui kembali suatu tatanan. Jika pembaharuan dikaitkan dengan hukum, maka pembaharuan hukum dapat diartikan sebagai suatu penataan kembali hukum agar hukum tersebut dapat berlaku sesuai tuntutan perkembangan jaman, dapat mengikuti perkembangan dan kebutuhan masyarakat yang sesuai dengan rasa keadilan dan norma serta nilai-nilai yang hidup di masyarakat. ${ }^{18}$ Dengan kata lain tujuan pembaharuan hukum adalah agar hukum tersebut dapat mengawal spirit kebaruan, termasuk pembaharuan moral dan integritas aparat penegak hukum dalam rangka penegakkan hukum untuk mengatasi masalah social, politik, ekonomi, dan hukum, sehingga hukum secara teori dapat berlaku secara yuridis, sosiologis, dan filosofis. ${ }^{19}$

Menegaskan kembali pembaharuan hukum di Indonesia, pemerintahan Jokowi-JK merumuskan visi untuk Indonesia yang

\footnotetext{
${ }_{17}$ Denny Indrayana, Amandemen UUD 1945: Antara Mitos dan Pembongkaran, (Bandung: Mizan Media Utama, 2007), 389.

18 Frans Hendra Winarta, "Prospek Pembaruan Hukum Pemerintahan Joko Widodo dan Muhammad Jusuf Kalla Periode 20 14-20 19", Bahan dalam Seminar Pengkajian Hukum Nasional Tahun 2014 (SPHN 20 I4), Jakarta, 2-3 Desember 2014, I.

19 lbid.
} 
berdaulat, mandiri, dan berkepribadian berdasartkan gotongroyong. Dalam rangka mewujudkan visi tersebut, dirumuskanlah 7 (tujuh) misi yang salah satunya adalah mewujudkan masyarakat maju, berkesinambungan, dan demokratris berdasarkan Negara hukum yang kemudian dijabarkan ke dalam komitmen berupa reformasi berokrasi dan pelayanan publik. Oleh karena itu, dapat dilihat bahwa Jokowi-JK memiliki pemahaman bahwa hukum menjadi dasar bagi kemajuan dan keseimbangan bangsa. ${ }^{20}$

Wujud dari visi dan misi kebijakan reformasi hukum tersebut sejalan dengan agenda pembangunan nasional dalam Rencana Pembangunan Nasional Menengah 2015-2019 (RPJMN 2015-2019), yaitu:

1. Menghadirkan kembali Negara untuk melindungi segenap bangsa dan memberikan rasa aman kepada seluruh warga Negara;

2. Membangun tata kelola pemerintahan yang bersih, efektif, demokratis, dan terpercaya; dan

3. Memperkuat kehadiran Negara dalam melakukan reformasi sistem dan penegakkan hukum yang bebas korupsi, kolusi, dan terpercaya. ${ }^{21}$

Berdasarkan RPJMN 2015-2019 tersebut, ada 3 (tiga) yang diinstruksikan oleh Jokowi-JK dalam kebijakan pembaharuan hukum dari hulu sampai ke hilir, yaitu:

1. Penataan regulasi untuk menghasilkan hukum yang berkualitas. Penataan dilakukan dengan membenahi peraturan perundangan-undangan yang dinilai menyulitkan dan tumpang tindih satu dengan yang lain;

2. Reformasi internal di instansi kejaksaan, kepolisian, dan di lingkup Kementerian Hukum dan HAM sehingga menghasilkan

20 Muh. Risnain, "Kesinambungan Politik Hukum Pemberantasanb Korupsi", artikel dalam Jurnal Rechtsvinding Media Pembinaan Hukum Nasional, Vol. 3, No. 3, Desember 20 I4, 3 I3.

2l Shanti Dwi Kartika, "Pembentukan Kebijakan Reformasi Hukum", artikel dalam Majalah Info Singkat Hukum Vol. VIII, No. 19///P3DI/Oktober/2016, 2. 
pelayanan dan penegakkan hukum professional sebagai revitalisasi hukum;

3. Pembangunan budaya hukum agar terbentuk kesadaran dan kepatuhan hukum di kalangan masyarakat. ${ }^{22}$

Sesuai dengan kebijakan hukum tersebut, maka dari segi konten pembaharuan pemikiran dalam metode pendekatan terhadap hukum tata negara dewasa ini telah mulai disadari dan dilaksanakan, terutama dalam kaitannya dengan pembinaan hukum. Kesadaran ini mulai tampak melalui pembahasan berbagai problem sosial ke dalam materi hukum tata negara, dengan mengingat adanya interaksi, interrelasi, dan interdependensi antara hukum dan perubahan-perubahan sosial.

Masalah-masalah baru timbul dalam masyarakat sebagai akibat dari proses pembanguan dan modernisasi. Hukum haruslah peka terhadap kebutuhan masyarakat dan berperan sebagai "agent of stability" maupun "agent of change", sehingga pendekatan baru terhadap Hkum Tata Negara akan menunjang pengembangannya lebih lanjut.

Pembaharuan terhadap Hukum Tata Negara hakekatnya menurut Siti Sundari Rangkuti adalah perluasan obyek Hukum Tata Negara yang semula hanya sebatas memperlajari negara semata-mata sebagai suatu organisasi kemasyarakatan. ${ }^{23}$ Perkembangan dan kebutuhan ilmiah mengakibatkan pergeseran dalam obyek Hukum Tata Negara untuk kemudian menjadi tiga aspek pokok, yaitu Pertama, individu dan masyarakat. Kedua, organisasi negara. Dan ketiga, produk-produk hukum [rechtsproductie]. ${ }^{24}$

Produk-produk hukum atau perundang-undangan sebagai obyek hukum tata negara mengandung unsur dinamika yang erat hubungannya dengan gerak dan kebutuhan-kebutuhan individu

22 lbid.

${ }^{23}$ Departemen Hukum Tata Negara Universitas Airlangga, Dinamika Perkembangan Hukum Tata Negara dan Hukum Lingkungan, (Surabaya; Airlangga University Press, 2008), 12.

24 lbid. 
dalam masyarakat dan pertumbuhan organisasi negara. Mengingat adanya interrelasi antara hukum tata negara dan perubahanperubahan sosial, maka nyatalah bahwa yang penting dalam hukum tata negara bukanlah sekedar mempelajari UUD dan peraturan perundangan saja, tapi tekanan hendaklah lebih diberikan kepada proses terjadinya UU. Untuk mementukan subtansi hukum yang sesuai, proses pembentukan ini haruslah memperhatikan perkembangan dan kebutuhan masyarakat dengan segala aspeknya, baru kemudian masalah tehnik perancangannya menjadi tugas "legislative drafter". Walaupun suatu UUD merupakan legal document, tetapi proses pembentukkannya berkaitan erat dengan bidang politik, sehingga besarlah peranan diffrerent times, different images dalam menetapkan subtansinya.

Hubungan timbal balik antara hukum dan kenyataankenyataan masyarakat memerlukan analisa terhadap peranan hukum dalam mendorong terjadinya perubahan-perubahan sosial. Pengaruh tidak langsung akan terasa pada pranata-pranata sosial tertentu, seperti pendidikan, keluarga, politik, ekonomi, administrasi, dan sebagainya. Di sini pembaharuan sistem akan mendorong terjadinya perubahan-perubahan dalam masyarakat. Pengaruh langsung dapat berupa menggeser dan mengubah nilainilai yang berlaku dalam masyarakat yang sifatnya menghambat pembangunan dengan membentuk hukum-hukum baru sebagai sarana pengendalian.

Dengan demikian jelaslah, bahwa hukum merupakan refleksi dan sebaliknya pula mempengaruhi arah dari perubahan sosial, karena hukum bukan saja gejala dari masyarakat, tapi merupakan unsur dari masyarakat. Di mana ada hukum, di situ ada masyarakat [ubi ius, ibi societas].

Dalam konteks ini diperlukan kesadaran dan pembaharuan cara berpikir di bidang hukum tata negara, sehingga legal narrowness yang disebabkan kurang luasnya perbendaharaan hukum tidak lagi muncul dalam bentuk legal thinking atau juridisch denken sematamata, yang mengakibatkan cara berpikir yang picik dalam bentuk 
menirukan bunyi peraturan-peraturan saja. Hukum Tata Negara tidak saja memperhatikan sudut pandang formal, tapi juga sudut fungsional, sehingga akan selalu bersifat dinamis.

\section{Subtansi-Subtansi Hukum Tata Negara Indonesia Yang Perlu Dilakukan Pembaharuan}

Berdasarkan pokok-pokok permasalahan di bidang Hukum Tata Negara Indonesia sebagaimana telah dipaparkan sebelumnya, maka pada paparan berikut disampaikan subtansi-subtansi hukum tata Negara Indonesia yang perlu dilakukan pembaharuan. Pembahasan dibatasi pada tiga subtansi pokok yang menurut penulis sangat urgen untuk dilakukan pembaharuan, yaitu tentang keberadaan lembaga perwakilan rakyat, kajian perekonomian nasional, dan kesejahteraan rakyat, serta keagamaan dan pendidikan. Masalah kelembagaan Negara menjadi urgen karena masih adanya ketimpangan struktur, tugas dan fungsi dari kelembagaan Negara. Sedangkan kajian perekonomian nasional, dan kesejahteraan rakyat, serta keagamaan dan pendidikan perlu diangkat karena pembahasan tentang masalah tersebut biasanya sangat minim dalam hukum tata negara padahal hal tersebut juga termasuk aspek yang harus dikaji dalam Hukum Tata Negara sebagai manisfestasi dari welfare state yang menjadi cita Negara hukum itu sendiri.

\section{Sistem Bikameral dan Disharmoni tugas dan wewenang DPR dan DPD sebagai Lembaga Perwakilan Rakyat}

Perubahan UUD 1945 telah mengembalikan sistem ketatanegaraan khususnya kelembagaan negara pada proporsinya, yaitu mengembalikan eksistensi lembaga legislatif ke sistem bikameral. Amandemen ini menempatkan MPR tidak lagi sebagai supremasi tetapi sebagai lembaga tinggi negara yang keanggotaannya meliputi DPR dan DPD. Pertimbangan logis Indonesia mengadopsi sistem bikameral dengan membentuk kamar ke dua setelah DPR yaitu DPD adalah untuk mewadahi keterwakilan yang berbeda, yaitu pusat dan daerah. 
Tetapi perubahan UUD 1945 tersebut tidak benar-benar membentuk sistem bicameral murni, tetapi lebih ke arah soft bicameral, bahkan pada batas-batas terentu lebih ke arah tricameral, yaitu dengan menempatkan MPR sebagai kamar ketiga. ${ }^{25}$ Dalam sistem bikameral murni, sebagaimana di Amerika Serikat. Lembaga perwakilan Amerika serikat terdiri dari Majelis Tinggi (Senat), dan Majelis Rendah (House of Representatives). Ketika akan memutuskan suatu permasalahan negara, kedua institusi ini membentuk forum gabungan 'joint session' yang bernama Congres (lembaga semacam MPR). Jadi Congres disini hanyalah forum pertemuan saja atau sidang gabungan Senat dan House of Representatives, bukan suatu lembaga negara/lembaga tetap. Ketika terjadi deadlock dan/atau Congress selaku forum diperhadapkan pada suatu keputusan, maka sebagaimana terjadi di Amerika Serikat, kedua kamar tersebut diwakili secara proporsional bertemu dalam suatu komisi bentukan bersama yang disebut 'Conterence'. Model conference ini diberlakukan tidak saja pada pelaksanaan fungsi legislasi, tetapi juga pada fungsi pengawasan. ${ }^{26}$

Perubahan UUD 1945 tersebut telah menjadikan DPR sebagai lembaga legislatif yang digdaya. ${ }^{27}$ Menurut Saldi Isra, amandemen UUD 1945 telah melahirkan DPR yang unggul - yaitu

\footnotetext{
25 Philipus M. Hadjon, "Eksistensi, Kedudukan, dan Fungsi MPR sebagai Lembaga Negara dalam Sistem Ketatanegaraan Republik Indonesia", dalam Departemen Hukum Tata Negara, Dinamika Perkembangan Hukum Tata Negara dan Hukum Lingkungan, (Surabaya: Departemen Hukum Tata Negara FH Hukum Unair, 2008), 191.

26 Terdapat perbedaan antara 'joint session' dengan 'conference'. Joint session disediakan untuk menyelesaikan wewenang bersama dalam Congress, seperti penetapan UU secara bersama-sama antara Senate dan House of Representatives. Sedangkan conference disediakan untuk menyelesaikan deadlock yang berkaitan dengan kewenangan mandiri masing-masing kamar. Misalnya suatu RUU yang diajukan oleh House of Representatives ditolak oleh Senate begitu sebaliknya, maka penyelesaiannya dilakukan melalui conference. Dalam hal ini masing-masing kamar memiliki kewenangan masing-masing.

27 Titik Triwulan Tutik, Konstruksi Hukum Tata Negara Indonesia Pasca Amandemen UUD 1945, (Jakarta: Kencana Prenada Media Group, 2010), 168.
} 
mengukuhkan hegemoni DPR dalam sistem trikameral. ${ }^{28}$ Keadaan demikian dibenarkan oleh Jimly Asshiddiqie. Menurut Jimly:

“Amandemen UUD 1945 telah mengadopsi sistem parlemen becameral yang bersifat soft - yang meletakkan DPR lebih kuat daripada DPD. Hal ini tampak dari kewenangan DPD yang hanya bersifat tambahan dan terbatas pada hal-hal yang berkaitan langsung dengan kepentingan daerah. ${ }^{29}$

Melihat kenyataanya demikian, dalam ketatanegaraan khususnya pada lembaga perwakilan rakyat, telah terjadi disharmonisasi kedudukan dan fungsi antara DPD dan DPR. Hal ini disebabkan karena terjadi ketidakseimbangan antara tugas dan wewenang yang diemban antara DPD dan DPR selaku Lembaga Perwakilan Rakyat. Lebih jauh lagi Undang-Undang Nomor 27 Tahun 2009 (UUMD3 2009) yang mengubah Undang-Undang Nomor 22 Tahun 2003 (UUMD 2003) semakin memperkuat hegemoni DPR atas DPD dan mengukuhkan sistem tiga kamar (tricameral system) bukan sistem dua kamar (bicameral system).

Posisi DPD adalah sekadar partner DPR. DPD yang dipilih langsung oleh rakyat seperti DPR, ternyata tidak memiliki kewenangan yang sama seperti DPR dalam membuat legislasi. ${ }^{30} \mathrm{Hal}$ ini akibat munculnya beberapa pandangan. Pertama, anggota DPR sesungguhnya telah mencerminkan kepentingan daerah-daerah yang ada di Indonesia. Kedua, kecilnya peran DPD akibat muncul kekhawatiran terjadinya konflik antara DPR dengan DPD dalam proses pembuatan UU yang sulit dicari jalan keluarnya. ${ }^{31}$

\footnotetext{
${ }^{28}$ Saldi Isra, "Penataan Lembaga Perwakilan Rakyat, Ssistem Trikameral di Tengah Supremasi DPR", Jurnal Konstitusi, Vol. I No. I, Juli 2004, 129.

29 Jimly Asshiddiqie, Format Kelembagaan Negara dan Pergeseran Kekuasaan dalam UUD 1945, (Yogyakarta: FH UII Press, 2005), 52.

30 Maswardi Rauf, "Perkembangan UU Bidang Politik Pasca Amandemen UUD 1945", Makalah Pembanding Tulisan makalah Prof. Dr. Jimly Asshiddiqie, SH berjudul Struktur Ketatanegaraan Indonesia Setelah Perubahan Keempat UUD Tahun 1945 yang disajikan dalam Seminar dan Lokakarya Pembangunan Hukum Nasional VIII yang diselenggarakan oleh Badan Pembinaan Hukum Nasional Departemen Kehakiman dan Hak Asasi Manusia RI di Denpasar Bali, pada tanggal 14-I8 Juli 2003, 5.

${ }^{31}$ Ibid.
} 
Melihat kenyataan demikian, DPD ke depan harus diberdayakan kembali dengan melakukan perubahan terhadap UUD 1945 dengan menyetarakan tugas dan fungsi antara DPD dan DPR.

Kekuasaan Pemerintahan Negara dan Kedudukan Wakil Presiden dalam hal kedudukan yang mandiri Wakil Presiden sebagai satu institusi sendiri

Perubahan UUD 1945 telah menempatkan bahwa antara Presiden dan Wakil Presiden merupakan satu institusi (dwi tunggal) - maka kedudukan Wakil Presiden juga sama dengan kedudukan Presiden, yaitu satu kesatuan yang tidak dapat dipisahkan. Karena itu mereka berdua dipilih dalam satu paket. Sebagaimana dijelaskan dalam Pasal 6A UUD 1945 setelah perubahan, "Presiden dan wakil presiden dipilih dalam satu pasangan calon secara langsung oleh rakyat dalam suatu pemilihan umum".

Berdasarkan ketentuan tersebut, sebagaimana Presiden maka kedudukan Wakil Presiden adalah kuat. Artinya kedudukan Wakil Presidenpun tidak dapat diganggu gigat oleh lembaga negara lain, termasuk DPR. Meski demikian secara fungsi dan wewenangnya memiliki perbedaan, karena keberadaannya baru diakui ketika Presiden dalam keadaan berhalangan.

Meski demikian pada kenyataan, peran dan kedudukan Wakil Presiden dalam hal kedudukan yang mandiri Wakil Presiden sebagai satu institusi sendiri, dalam sistem ketatanegaraan Republik Indonesia secara konstitusional baik sebelum maupun setelah perubahan UUD 1945 dapat dikatakan belum mendapat kejelasan. ${ }^{32}$ Menurut Adi Sumardiman, dkk., setidaknya ada tiga hal yang menyebabkan tidak jelasnya peran dan kedudukan Wakil Presiden. Pertama, kedudukan Wakil Presiden adalah sebagai Pembantu Presiden, sebagaimana diatur di dalam UUD 1945 Pasal 4 ayat (2). Sebagai Pembantu Presiden kedudukan Wakil Presiden

32 Dhanang Alim Maksum, "Tugas dan Fungsi Wakil Presiden di Indonesia", artikel dalam Lex Crimen, Vol. IV, No. I, Januari-Maret 20I 5, 123. 
menjadi setara dengan menteri yang juga sama-sama sebagai Pembantu Presiden. Wakil Presiden hanya merupakan the second man (orang kedua); Kedua, Wakil Presiden tidak bertanggung jawab kepada Presiden, sebagaimana layaknya status menteri sebagai Pembantu Presiden yang bertanggung jawab langsung kepada Presiden; dan Ketiga, dalam tradisi dan praktik ketatanegaraan, belum pernah ada Wakil Presiden yang menyampaikan pertanggung jawaban kepada MPR atau kepada rakyat. Pertanggung jawaban selalu dibebankan kepada Presiden. Karena itu, posisi Wakil Presiden sebagai pembantu Presiden menjadi kurang memiliki kewenangan dalam pengambilan keputusan. ${ }^{33}$

Dhanang Alim Maksum, lebih lanjut memaparkan beberapa penyebab kekurangjelasan peran dan kedudukan Wakil Presiden. Pertama, dalam sistem pemerintahan di Indonesia sejak tahun 1945 hingga sekarang, jabatan Wakil Presiden tidak mempunyai wewenang apa-apa. Fungsinya hanya menggantikan Presiden; Kedua, dalam perjalanan sejarah ketatanegaraan di Indonesia, Negara Republik Indonesia pernah tidak memiliki Wakil Presiden. ${ }^{34}$ Meski demikian pada kenyataannya, meskipun tanpa Wakil Presiden, pemerintahan dapat berjalan. Ketiga, hubungan Wakil Presiden dengan Presiden pada setiap masa mempunyai karakter yang berbeda-beda.

\footnotetext{
${ }^{33}$ Adi Sumardiman, dkk., Wawasan Nusantara, (Jakarta: Kerjasama Yayasan Harapan Nusantara dan Surya Indah, 1982), 15.

34 Pada masa pemerintahan Soekarno (1956-1967), Presiden berjalan sendiri menjalankan roda pemerintahan, tanpa didampingi oleh Wakil Presiden. Mohammad Hatta yang diangkat sebagai Wakil Presiden pada tanggal 18 Agustus 1945, mengundurkan diri dari jabatannya pada tanggal I Desember 1956. Sejak Mohammad Hatta mengundurkan diri, jabatan Wakil Presiden tidak pernah diisi. Demikian pula, pada masa awal pemerintahan Soeharto (1967-1973). Presiden Soeharto diangkat oleh MPRS sebagai Pejabat Presiden, tanpa ada pengangkatan Pejabat Wakil Presiden. Pada waktu Sidang Istimewa tanggal 7-12 Maret 1967 yang mengeluarkan Ketetapan MPRS Nomor; XXXIII/MPRS/I967 mengenai pencabutan kekuasaan pemerintahan Soekarno sekaligus menetapkan Jenderal Soeharto sebagai Presiden, posisi Wakil Presiden tidak disinggung. Indonesia baru kembali memiliki Wakil Presiden, setelah diangkatnya Sri Sultan Hamengkubuwono IX pada tanggal 25 Maret 1973.
} 
Kenyataan-kenyataan demikian menjadikan kedudukan Wakil Presiden dalam suatu sistem ketatanegaraan menjadi tawar antara ada dan ketiadaannya. Sehingga sering dikatakan bahwa kedudukan Wakil Presiden ibarat sebagai "ban serep". ${ }^{35}$

Kondisi demikian harus mendapat perhatian khusus dalam Hukum Tata Negara, terutama dalam pengkajian UUD 1945 dan regulasi lainnya. Artinya, kedudukan, tugas dan wewenang Wakil Presiden ini harus kembali menjadi agenda dalam perubahan UUD 1945 berikutnya agar benar-benar terjadi keseimbangan yang proporsional antara tugas dan wewenang Presiden dan Wakil Presiden. Atau setidaknya ada pembagian yang jelas antara masingmasing tugas dan wewenang tersebut.

\section{Penutup}

Negara hukum merupkan pilihan yang tepat untuk Indonesia yang hendak mewujudkan walfare state sebagai cita Negara hukum itu sendiri, yaitu sebagaimana termaktub dalam pembukaan UUD 1945, yaitu memajukkan kesejahteraan umum, mencerdaskan kehidupan bangsa, dan ikut melaksanakan ketertiban dunia yang berdasarkan kemerdekaan, perdamaian abadi, dan keadilan sosial.

Dalam rangka mewujdukan tujuan tersebut, maka pembaharuan terhadap Hukum Tata Negara Indonesia adalah keniscayaan, karena hukum tata Negara merupakan hukum yang mengatur sendi-sendi kehidupan dalam berbangsa dan bernegara termasuk didalamnya adalah menyangkut tujuan dari Negara itu sendiri.

Pembaharuan Hukum Tata Negara Indonesia harus menyangkut semua aspek yaitu menyangkut pendekatan dan strategi serta subtansi yang disesuaikan dengan tuntutan perkembangan jaman, dapat mengikuti perkembangan dan kebutuhan masyarakat yang sesuai dengan rasa keadilan dan norma serta nilai-nilai yang hidup di masyarakat. Dengan demikian

35 Jimly Asshiddiqie, Pokok-Pokok Hukum Tata Negara Indonesia Pascareformasi, (Jakarta: Bhuana Ilmu Populer, 2008), 33I. 
Hukum Tata Negara Indonesia dapat menjadi sumber belajar tidak saja dalam lingkup nasional tetapi juga dalam lingkup global.

\section{Daftar Pustaka}

Asshiddiqie, Jimly. Format Kelembagaan Negara dan Pergeseran Kekuasaan dalam UUD 1945. Yogyakarta: FH UII Press, 2005.

Asshiddiqie, Jimly. Pokok-Pokok Hukum Tata Negara Indonesia Pascareformasi. Jakarta: Bhuana Ilmu Populer, 2008

Azhary, Muhammad Tahir. Negara Hukum: Suatu Studi tentang Prinsip-prinsipnya Dilihat dari Segi Hukum Islam, Implementasinya pada Periode Negara Madinah dan Masa Kini. Jakarta: Bulan Bintang, 1992

Departemen Hukum Tata Negara Universitas Airlangga. Dinamika

Perkembangan Hukum Tata Negara dan Hukum Lingkungan. Surabaya; Airlangga University Press, 2008

Hadjon, Philipus M., “Eksistensi, Kedudukan, dan Fungsi MPR sebagai Lembaga Negara dalam Sistem Ketatanegaraan Republik Indonesia", dalam Departemen Hukum Tata Negara, Dinamika Perkembangan Hukum Tata Negara dan Hukum Lingkungan. Surabaya: Departemen Hukum Tata Negara FH Hukum Unair, 2008.

Hadjon, Philipus M., "Pembagian Kewenangan Pusat dan Daerah", Makalah. Disampaikan pada Semiloka Rekonstruksi Politik Hukum Otonomi Daerah Yang Berbasis pada Kemandirian dan Demokratisasi di Daerah (Strategi Revisi UU No. 22 dan 25 Tahun 1999) di Malang (18-20 Pebruari 2001)

Hadjon, Philipus M., Perlindungan Hukum bagi Rakyat di Indonesia. Surabaya: Bina Ilmu, 1987

Indrayana, Denny, "Negara Hukum Pasca Soeharto: Transisi Menuju Demokrasi vs Korupsi", Jurnal Konstitusi, Mahkamah Konstitusi RI Vol. 1 No. 1 (Juli 2004)

Indrayana, Denny, Amandemen UUD 1945: Antara Mitos dan Pembongkaran, Bandung: Mizan Media Utama, 2007. 
Isra, Saldi, "Penataan Lembaga Perwakilan Rakyat, Sistem Trikameral di Tengah Supremasi DPR", Jurnal Konstitusi, Vol. 1 No. 1 (Juli 2004)

Kartika, Shanti Dwi, "Pembentukan Kebijakan Reformasi Hukum", artikel dalam Majalah Info Singkat Hukum Vol. VIII, No. 19/I/P3DI/Oktober/2016 (Oktober 2016)

Kusuma, R.M. Ananda B. "Sistem Pemerintahan Indonesia". Jurnal Konstitusi, Mahkamah Konstitusi RI Vol. 1 No. 1, Juli 2004.

Majelis Permusyawaratan Rakyat RI, Panduan Pemasyarakatan Undang-Undang Dasar Negara republik Indonesia Tahun 1945 dan Ketetapan Majelis Permusyawaratan Rakyat Republik Indonesia, Jakarta: Sekretariat Jenderal MPR RI, 2012

Maksum, Dhanang Alim, “Tugas dan Fungsi Wakil Presiden di Indonesia", artikel dalam Lex Crimen, Vol. IV, No. 1 (JanuariMaret 2015)

Risnain, Muh., “Kesinambungan Politik Hukum Pemberantasanb Korupsi", artikel dalam Jurnal Rechtsvinding Media Pembinaan Hukum Nasional, Vol. 3, No. 3 (Desember 2014)

Sumardiman, Adi., dkk., Wawasan Nusantara, Jakarta: Kerjasama Yayasan Harapan Nusantara dan Surya Indah, 1982.

Tutik, Titik Triwulan, Konstruksi Hukum Tata Negara Indonesia Pasca Amandemen UUD 1945, Jakarta: Kencana Prenada Media Group, 2011.

Tutik, Titik Triwulan, Restorasi Hukum Tata Negara Indonesia Berdasrkan Undang-Undang Dasar Negara Republik Indonesia Tahun 1945, Jakarta: Prenada Media Group, 2017.

Wahjono, Padmo, Sistem Hukum Nasional dalam Negara Hukum Pancasila, Jakarta: Rajawali, 1983

Winarta, Frans Hendra, "Prospek Pembaruan Hukum Pemerintahan Joko Widodo dan Muhammad Jusuf Kalla Periode 2014-2019", Bahan dalam Seminar Pengkajian Hukum Nasional Tahun 2014 yang diselenggarakan oleh SPHN Jakarta (2-3 Desember 2014) 